\title{
COMPREHENSIVE ASSESSMENT OF THE WATER ECOLOGICAL SECURITY OF THE XIANGJIANG RIVER BASIN BASED ON PHYSICO-CHEMISTRY AND ORGANISM INDICES
}

\author{
Xu, X. $.^{*}-$ Sheng, D. ${ }^{1}-$ LI, G. ${ }^{1}-$ Chen, X. ${ }^{2}-$ WAng, X. ${ }^{3}-$ XIAO, C. ${ }^{3}-$ GAO, X. $.^{4,5}-$ Hu, C. \\ ${ }^{1}$ Hunan Institute of Water Resources and Hydropower Research \\ Changsha, Hunan 410007, China \\ ${ }^{2}$ Key Laboratory of Environmental Biology and Control, Ministry of Education \\ Hunan University, Changsha 410007, China \\ ${ }^{3}$ College of Hydrology and Water Resources, Hohai University \\ Nanjing, Jiangsu 210098, China \\ ${ }^{4}$ Hunan Provincial Academy of Science and Technology Consulting Co., Ltd. \\ Changsha 410004, China \\ ${ }^{5}$ Hunan Academy of Environmental Protection Science, Changsha 410004, China \\ *Corresponding author \\ e-mail:461416807@qq.com
}

(Received $19^{\text {th }}$ Oct 2018; accepted $28^{\text {th }}$ Jan 2019)

\begin{abstract}
The water ecological security of a river basin affects the vigorous growth of the regional economy and the healthy development of the ecological environment. Based on river physics, chemistry, and biological indicators, this study constructed a comprehensive assessment index system for the water ecological security of the Xiangiiang River Basin in China. The system consisted of 6 elements, and 18 indicators. This study used the analytic hierarchical process (AHP) to evaluate the water ecological security of the upstream, midstream, and downstream environments of the Xiangjiang River Basin. The results show that the overall ecological security of the upper and midstream portions of the Xiangjiang River Basin is relatively good, while the downstream section is at a general level. The three indicators that are given the most weight in the indicator system are the fish bio-loss index, the degree of ecological flow satisfaction, and the compliance rate of the water function zone. The less significant indicators are the natural wetland retention rate, riparian vegetation coverage, riparian human activity, and riverside connectivity. The research results of this study can provide a reference for the ecological restoration of regional rivers and the protection of Xiangjiang River.
\end{abstract}

Keywords: ecological security, water environment, indicator system, AHP, Xiangjiang River Basin

\section{Introduction}

Xiangjiang River, the mother river of Hunan Province, is an important tributary of the Yangtze River and the largest tributary of the Dongting Lake water system. The location of Xiangjiang River Basin is both in the radiating zone of the Yangtze River Economic Belt and in the South China Economic Circle. This basin is located in the most densely populated and economically developed region in Hunan Province and is an important grain production base in China. In the past two decades, with the increase in water 
consumption due to urbanization as well as industrial water and agricultural irrigation, some wastewater has been directly discharged into the Xiangjiang River, causing serious pollution concerning heavy metals, fecal coliforms, ammonia nitrogen, total phosphorus and chemical oxygen demand. When the indicators of the presence of these pollutants exceed standard values, aquatic biodiversity is reduced, which brings about problems with watershed resources and the ecological environment, and the pressure of sustainable development increases dramatically. In 2013, in order to protect the Xiangjiang River, the Government of Hunan Province issued the "Regulations on the Protection of the Xiangjiang River in Hunan Province" and launched the "No. 1 Key Project" for implementing the protection and treatment of the Xiangjiang River, which was then comprehensively carried out.

A river is the core of a river basin ecosystem. Rivers are often regarded as ecological corridors to provide good habitats for animals and plants. They are also sources of matter and energy (He, 2017). A river ecosystem is one of the most complex ecosystems on the planet. Water ecological security has evolved from environmental changes and ecological risk analysis. Since the International Institute for Applied Systems Analysis (IIASA) was first proposed in 1989 (Ji and Long, 2016; Pan et al., 2017), the concept of water ecological security has not been scientifically defined. At present, there are two levels of understanding of water ecological security: the generalized concept and the narrow concept (Chen and Zhou, 2005; Chen et al., 2013). According to the generalized concept, water ecological security is a complex ecosystem safeguard composed of natural water ecological security, economic-ecological security, and social-ecological security (Zhang et al., 2013; Chen et al., 2016). According to the narrow concept, water ecological security concerns the safety of the "human" aspect, which includes the safety of natural and semi-natural ecosystems (Wang and $\mathrm{Hu}, 2013$ ). The foundation of water ecological security assessment involves establishing a scientific indicator system and evaluation criteria. At present, there are some typical evaluation systems, such as the indicator species ecosystem evaluation method (Zhang et al., 2017), biological integrity index (Schnier et al., 2016), and the PSR (Pressure-State-Response) model (Sun et al., 2016). The PSR model was proposed by Canadian statisticians David J. Rapport and Tony Friend in 1979 (Rapport et al., 1979) and later developed by the Organisation for Economic Co-operation and Development (OECD) and the United Nations Environment Programme (UNEP) in the 1980s and 1990s. Based on the PSR framework, in order to better characterize the role of non-environmental indicators in ecosystem health assessment, the United Nations Commission on Sustainable Development (UNCSD) established the Driver-State-Response (DSR) framework in 1996 (Doran, 1996).

The assessment of water ecological security involves the analysis of numerous factors using various methods. The existing water ecological safety assessment framework, however, often attaches importance to ecological health, while ignoring the assessment of ecosystem service functions and ecological risks. Due to different interpretations of various indicators, the selected evaluation indicators differ. Even the same evaluation indicators can be given different evaluation connotations. Liu et al. (1989) used the cultivated land area as an indicator to characterize the ecological state. Other researchers believe that agricultural and urban land represent the pressure of human production and lifestyle on aquatic ecosystems ( $\mathrm{Li}$ et al., 2012). In addition, existing evaluation indicators are mostly based on the entire basin, administrative divisions, fixed wide grid, and different ecosystem types (Nödler et al., 2016). These indicators have the advantage of reflecting the integrity of the basin through convenient data collection, but they also 
have shortcomings, such as the one concerning the spatial differences that cannot adequately reflect ecological security. Therefore, a series of indicators are needed to measure the water ecological security statusIn this paper, based on the comprehensive assessment of the water ecological security in the Xiangjiang River Basin, the water ecological characteristics of the Xiangjiang River Basin are understood. The research results provide basic support for watershed water ecological protection and restoration, and provide scientific basis for the formulation of water resources and water ecological security planning by the national and local governments in China.

\section{Materials and methods}

\section{Overview of the study area}

The Xiangjiang River Basin $\left(110^{\circ} 31^{\prime} \mathrm{E}-114^{\circ} 15^{\prime} \mathrm{E}, 24^{\circ} 31^{\prime} \mathrm{N}-29^{\circ} 52^{\prime} \mathrm{N}\right)$ is located south of the Yangtze River, and north of the Nanling Mountains in China. It has a subtropical humid climate and is greatly affected by monsoons. The average annual temperature of the basin is $17.4^{\circ} \mathrm{C}$. The average annual evaporation of the basin is $1275.5 \mathrm{~mm}$. The average annual precipitation in the basin is $1490 \mathrm{~mm}$. The spatial and temporal distribution of rainfall is uneven. From April to June, the rainfall was concentrated, and the average annual rainfall is $617.9 \mathrm{~mm}$, accounting for $42.9 \%$ of the whole year; from July to September, the average annual rainfall is $318.2 \mathrm{~mm}$, accounting for $22.1 \%$ of the whole year; from October to March, the rainfall is only $504.7 \mathrm{~mm}$, accounting for $35.0 \%$ of the whole year. In terms of geographical distribution, there is a trend of more rainfall in the north and south, and less rainfall in the central areas. The main stream of the Xiangjiang River is $856 \mathrm{~km}$ long, with a drainage area of $94,600 \mathrm{~km}^{2}$. A total of $85,400 \mathrm{~km}^{2}$ of the drainage area is in Hunan Province, accounting for $90 \%$ of the total basin area. To be specific, the Xiangjiang River Basin refers to the section of the basin in Hunan Province. The Xiangjiang River Basin includes important urban centers such as Yongzhou City, Chenzhou City, Hengyang City, Shaoyang City, Loudi City, Zhuzhou City, Xiangtan City, Changsha City, Yueyang City, and Yiyang City. The elevation of the basin is high in the southwest and low in the east. The Xiangjiang River flows into Dongting Lake from the south. The water system in the basin is complicated, consisting of many tributaries. There are 2,157 tributaries in the basin with lengths greater than 5 kilometers. The two sides of the main stream of the Xiangjiang River are in the form of asymmetrical feathers. The right bank covers an area of $67,316 \mathrm{~km}^{2}$, accounting for $71.2 \%$ of the total area of the basin. The main tributaries of the Xiangjiang River (the Xiaoshui River, Chonglinshui River, Leishui River, Mishui River, Lushui River, and Liuyang River) flow from the right bank into the main stream. The area of the left bank is $27,433 \mathrm{~km}^{2}$, accounting for $28.8 \%$ of the total area of the basin. The main tributaries (the Qishui River, Zhengshui River, Juanshui River, Lianshui River, and Weishui River) flow from the left bank. The distribution of water system and hydrological stations as shown in Figure 1.

\section{Division of evaluation units}

Based on the boundaries of municipal administrative divisions within the basin, this study comprehensively considered the spatial overlapping relationships among natural geographic units, administrative divisions, and watershed environmental management 
units of the basin and the consistently divided evaluation unit of the combination. Using the ArcHydro hydrological analysis module of ArcGIS software, the ASTER GDEM V2 (30 m resolution) data jointly measured by National Aeronautics and Space Administration (NASA) and Ministry of Economy, Trade and Industry (METI) was used as the basic DEM data for river network information extraction in the Xiangjiang River Basin. Finally, areas in Yongzhou City and Chenzhou City were designated as the upstream evaluation units; areas in Hengyang City and Zhuzhou City were designated as the mid-stream evaluation units; and areas in Changsha City, Xiangtan City, and Loudi City were designated as the downstream evaluation units. Figure 2 is a interpretation map of the catchment area of the Xiangjiang River Basin.

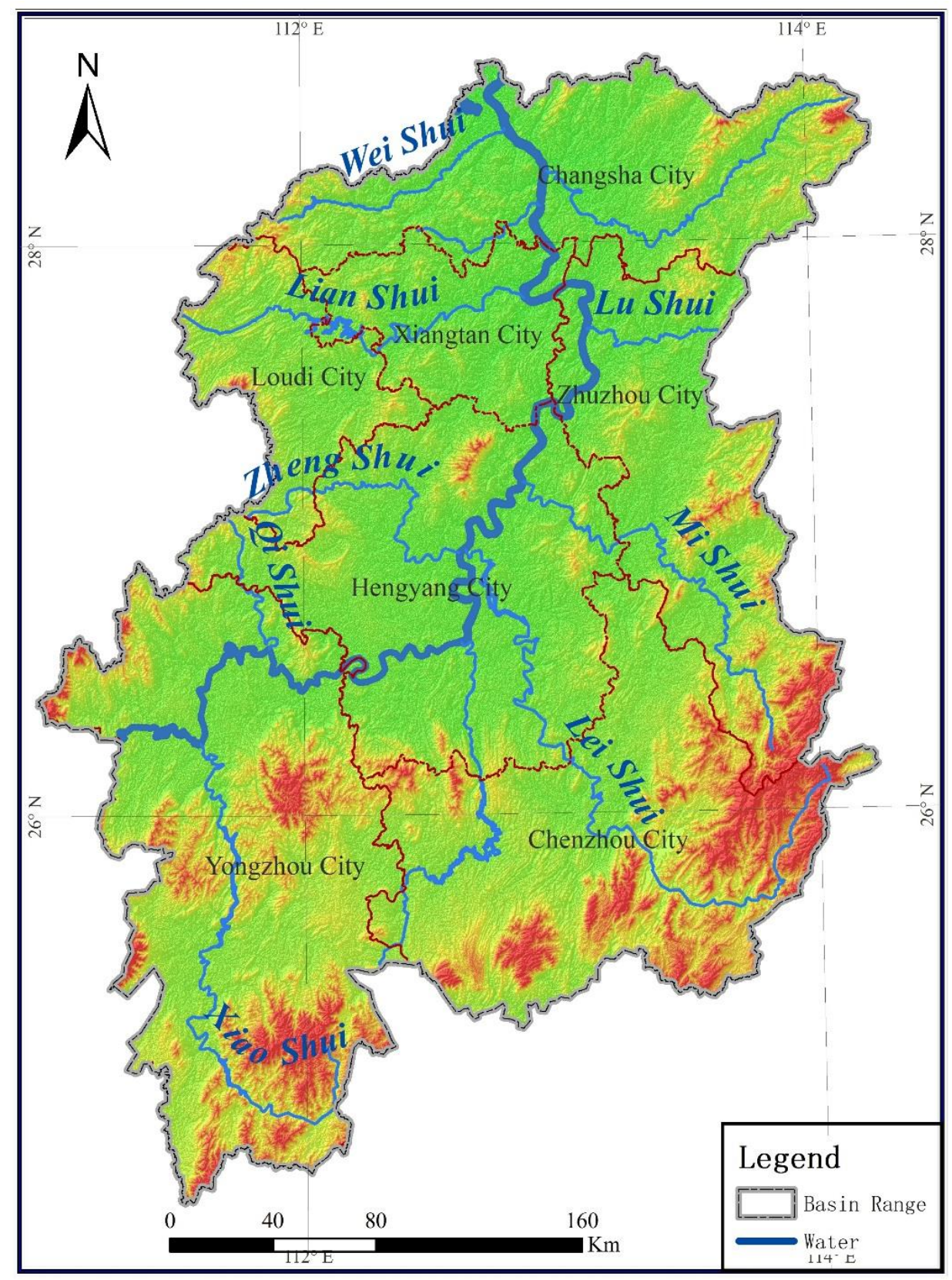

Figure 1. Distribution of the water system and hydrological stations in the Xiangjiang River Basin 


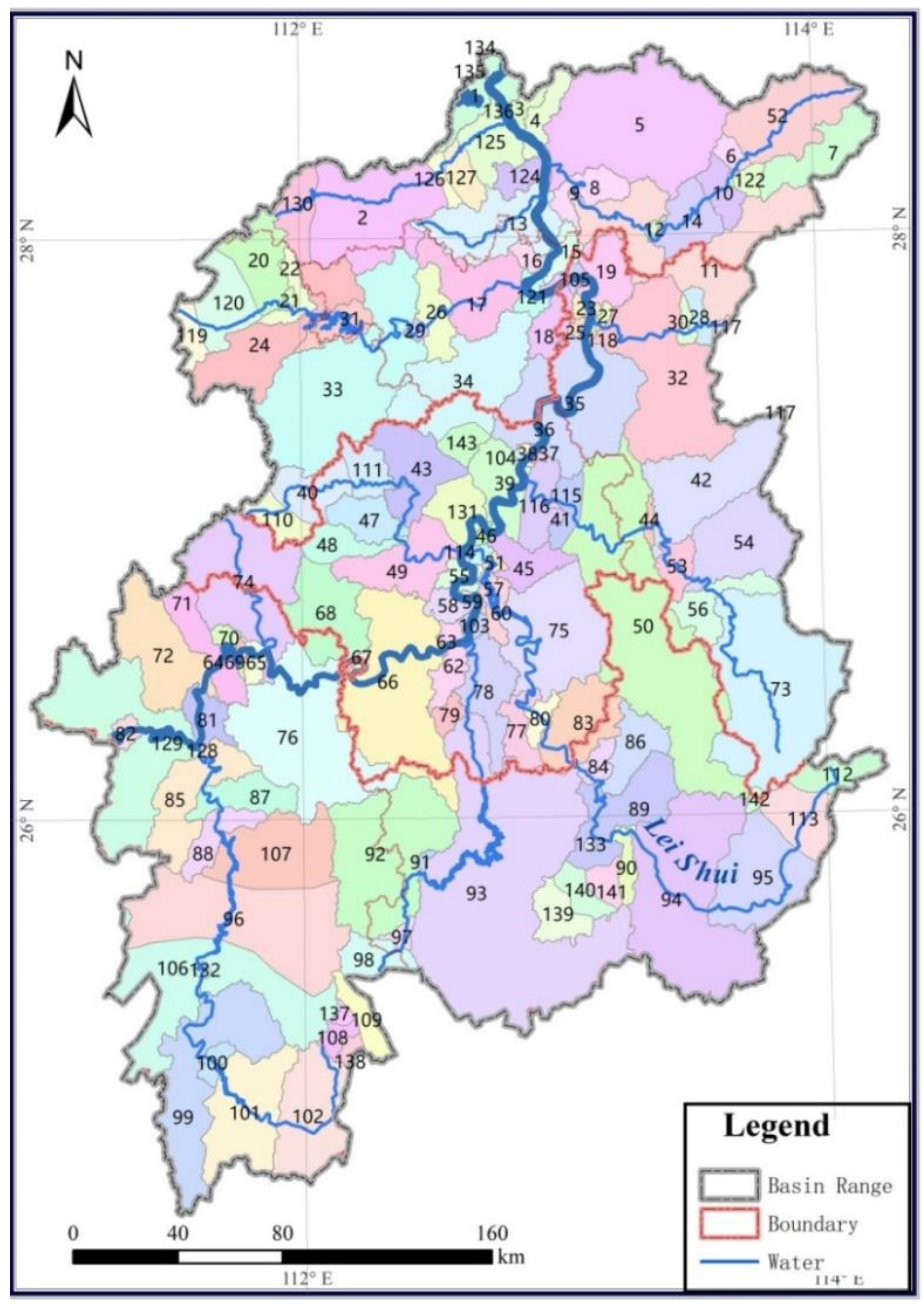

Figure 2. Interpretation map of the catchment area of the Xiangjiang River Basin

\section{Construction of a comprehensive evaluation index system}

According to previous research, the water ecosystem safety of a river basin means that the basin ecosystem is in a stable and sustainable state, maintaining physical, chemical, and biological integrity, providing humans with different ecological products or service functions, and having a certain resilience with respect to natural and human interference, as well as adjustment and repair capabilities. While assessing the water ecosystem safety through a series of indicators, we often tend to the principles of science, systems, conciseness, and operability. There are many water ecosystem safety assessment methods according to the previous studies (Dai et al., 2015; Lin et al., 2016; Wang et al., 2016). Among them, the AHP is a useful tool for providing qualitative and quantitative assessment to decision makers, which enables managers to evaluating the complicated indicator system (Yoshimatsu and Abe, 2006; Haji et al., 2016). In this study, therefore, the AHP was used to construct a comprehensive evaluation index system for water ecological security in Xiangjiang River Basin. This indicator system contains 18 indicators related to six aspects: hydrology and water resources, physical structure, water quality, biology, water ecological management, and social service functions (Table 1). 
Table 1. Comprehensive evaluation index system for water ecological security in the Xiangjiang River Basin

\begin{tabular}{|c|c|c|c|c|}
\hline $\begin{array}{l}\text { Target } \\
\text { layer }\end{array}$ & $\begin{array}{l}\text { Factor } \\
\text { layer }\end{array}$ & Indicator layer & Indicator description & Data Sources \\
\hline \multirow{10}{*}{$\begin{array}{l}\text { Water } \\
\text { ecological } \\
\text { security }\end{array}$} & \multirow{2}{*}{$\begin{array}{l}\text { Hydrology } \\
\text { and water } \\
\text { resources }\end{array}$} & $\begin{array}{l}\text { The flow process variation } \\
\text { degree }\end{array}$ & $\begin{array}{c}\text { Reflects and evaluates the influence of water resources development } \\
\text { and utilization above the monitoring section of river reach on the } \\
\text { hydrological situation of river reach }\end{array}$ & \begin{tabular}{|c|} 
Hunan Hydrological Network \\
(http://61.187.56.156/wap/index_sq.asp) The flow and water \\
level data of all hydrological stations in the basin of the \\
Xiangjiang River Basin from 1996 to 2015
\end{tabular} \\
\hline & & $\begin{array}{l}\text { The degree of ecological } \\
\text { flow satisfaction }\end{array}$ & Reflects the degree of ecological flow satisfaction of the main section & $\begin{array}{c}\text { Hunan Hydrological Network } \\
\text { (http://61.187.56.156/wap/index_sq.asp) Three stations from } \\
\text { Guiyang, Hengshan and Xiangtan from } 1996 \text { to } 2017 \\
\end{array}$ \\
\hline & \multirow{5}{*}{$\begin{array}{l}\text { Physical } \\
\text { structure }\end{array}$} & Riverbank Stability & $\begin{array}{c}\text { Shows whether the indicators reflect the stability of the river bank, } \\
\text { i.e., is readily eroded }\end{array}$ & $\begin{array}{c}\text { The main river course is counted by Google Earth software. } \\
12 \text { sampling points are selected randomly and evenly in the } \\
\text { main river course within the scope of the river basin. The } \\
\text { statistical time is } 2017 \text {. }\end{array}$ \\
\hline & & $\begin{array}{l}\text { Vegetation coverage on } \\
\text { river banks }\end{array}$ & $\begin{array}{l}\text { Reflects whether the structure and function of the riparian zone are in } \\
\text { good condition }\end{array}$ & $\begin{array}{l}\text { NDVI product data using the official MODIS website } \\
\text { (https://modis.gsfc.nasa.gov/) MOD13Q1 satellite. }\end{array}$ \\
\hline & & $\begin{array}{l}\text { Degree of human activity } \\
\text { in the riparian zone }\end{array}$ & $\begin{array}{c}\text { The focus of the survey is to assess nine types of human activities in } \\
\text { the riparian zone and its adjacent area: riverbank rigid masonry, sand } \\
\text { mining, coastal buildings (houses), roads (or railways), landfills or } \\
\text { dumps, riverside parks, degree of impact on water ecosystems, } \\
\text { pipelines, mining, agricultural farming, livestock farming, etc. }\end{array}$ & \begin{tabular}{|}
$\begin{array}{c}\text { Monitoring of riverside belts on the left and right sides of the } \\
\text { river in an on-site survey (2017) }\end{array}$ \\
\end{tabular} \\
\hline & & $\begin{array}{l}\text { River connection barrier } \\
\text { condition }\end{array}$ & $\begin{array}{c}\text { The main survey assesses river migration of biological species such as } \\
\text { fish and the blocking of water flow and nutrient transport, which can } \\
\text { be used to characterize river water ecological security. }\end{array}$ & $\begin{array}{l}\text { Statistics of the main river channel using Google Earth } \\
\text { software. The statistical time is } 2017 .\end{array}$ \\
\hline & & $\begin{array}{l}\text { The natural wetland } \\
\text { retention rate }\end{array}$ & $\begin{array}{c}\text { Reflect the pros and cons of the state of the river's ecological } \\
\text { environment }\end{array}$ & $\begin{array}{l}\text { Land use classification product data using the MODIS } \\
\text { website (https://modis.gsfc.nasa.gov/) MOD12Q1 satellite. }\end{array}$ \\
\hline & \multirow{3}{*}{$\begin{array}{l}\text { Water } \\
\text { quality }\end{array}$} & $\begin{array}{l}\text { Dissolved Oxygen } \\
\text { Concentration }\end{array}$ & $\begin{array}{c}\text { Dissolved oxygen is very important for aquatic animals and plants. } \\
\text { DO values that are too high or too low are harmful to aquatic } \\
\text { organisms, and the suitable range is } 4-12 \mathrm{mg} / \mathrm{L} \text {. }\end{array}$ & $\begin{array}{l}\text { Observation data of hydrological station from Hunan } \\
\text { Hydrological and Water Resources Survey Bureau in } 2015\end{array}$ \\
\hline & & $\begin{array}{l}\text { Oxygen-poor organic } \\
\text { pollution status }\end{array}$ & $\begin{array}{c}\text { Reflects the content of organic matter in water, based on the } \\
\text { permanganate index, chemical oxygen demand, five-day biochemical } \\
\text { oxygen demand, ammonia nitrogen and four other items to evaluate } \\
\text { the oxygen consumption of rivers }\end{array}$ & $\begin{array}{l}\text { Observation data of hydrological station from Hunan } \\
\text { Hydrological and Water Resources Survey Bureau in } 2015\end{array}$ \\
\hline & & $\begin{array}{l}\text { Heavy metal pollution } \\
\text { status }\end{array}$ & $\begin{array}{l}\text { Five items, i.e., arsenic, mercury, cadmium, chromium (hexavalent) } \\
\text { and lead were selected to assess the metal pollution status of water. }\end{array}$ & $\begin{array}{l}\text { Concentration data of measured heavy metal pollutants at } \\
\text { hydrological stations from Hunan Hydrological and Water } \\
\text { Resources Survey Bureau in } 2015\end{array}$ \\
\hline
\end{tabular}




\begin{tabular}{|c|c|c|c|c|}
\hline $\begin{array}{l}\text { Target } \\
\text { layer }\end{array}$ & $\begin{array}{l}\text { Factor } \\
\text { layer }\end{array}$ & Indicator layer & Indicator description & Data Sources \\
\hline & & $\begin{array}{l}\text { Water function area } \\
\text { compliance index }\end{array}$ & $\begin{array}{c}\text { Reflects the level of ecological environmental protection and resource } \\
\text { utilization }\end{array}$ & $\begin{array}{c}\text { Assessment of the monitoring sections of the upstream, } \\
\text { midstream and downstream of the Xiangjiang River Basin. } \\
\text { The proportion of the number of compliance points in the } \\
\text { water functional zones during the year of } 2015 \text {. }\end{array}$ \\
\hline & Biology & Fish Bio-Loss Index & Reflects the quality of aquatic ecosystems & $\begin{array}{c}\text { Survey data on fishery resource flows obtained from } 8 \\
\text { sampling points in the Xiangjiang River Basin } \\
\text { (November-December 2008, February-December } 2009 \text { and } \\
\text { February-September 2010, } 30 \text { times in total) }\end{array}$ \\
\hline & \multirow{3}{*}{$\begin{array}{c}\text { Water } \\
\text { ecological } \\
\text { management }\end{array}$} & $\begin{array}{c}\text { Sewage centralized } \\
\text { treatment efficiency index }\end{array}$ & Reflects the ability of water ecosystems to treat wastewater & Sewage treatment plant operation survey data \\
\hline & & \begin{tabular}{|l|} 
Soil erosion control index \\
\end{tabular} & $\begin{array}{c}\text { Reflects the intensity of soil erosion and the implementation of } \\
\text { control measures }\end{array}$ & $\begin{array}{c}\text { Urban soil erosion area survey data, the third remote sensing } \\
\text { survey of soil and water loss in hunan province organized by } \\
\text { Hunan Water Resources Department in } 2015 \text {. }\end{array}$ \\
\hline & & Hazard Source Risk Index & $\begin{array}{l}\text { Reflects the extent to which the source of the hazard affects the } \\
\text { ecosystem }\end{array}$ & $\begin{array}{l}\text { Hazard source survey and evaluation data of major industrial } \\
\text { parks (2017) }\end{array}$ \\
\hline & \multirow{3}{*}{$\begin{array}{l}\text { Social } \\
\text { service } \\
\text { function }\end{array}$} & Flood Control Indicators & Reflects the safe discharge capacity of the river & $\begin{array}{c}\text { Data sourced from the "Xiangjiang River Basin } \\
\text { Comprehensive Planning Report" }\end{array}$ \\
\hline & & $\begin{array}{l}\text { Public Satisfaction } \\
\text { Indicator }\end{array}$ & $\begin{array}{l}\text { Reflects the public's satisfaction with river landscapes, aesthetic } \\
\text { values, etc. }\end{array}$ & $\begin{array}{l}\text { Collected and processed relevant information through } \\
\text { questionnaires }\end{array}$ \\
\hline & & \begin{tabular}{|c|} 
Centralized drinking water \\
source safety guarantee \\
compliance rate public \\
satisfaction index
\end{tabular} & Reflects the safety of water & $\begin{array}{c}\text { National Safe Drinking Water Source Safety Assessment } \\
\text { Indicators }\end{array}$ \\
\hline
\end{tabular}




\section{Indicator calculation method and indicator assignment}

Based on the river water environment and ecological characteristics of the Xiangjiang River Basin, the standard values for river water ecology evaluation were determined. The calculation and assignment of each indicator utilized the following principles: (a) If there were specific applicable standards and industry norms in the country, the national standards and norms were preferred; (b) the relevant research results in China and abroad were used for reference; (c) indicators were standardized. The closer a detected indicator is to the natural state or the less a detected indicator is affected by human activities, the higher the score given to the indicator.

The flow process variation degree $(\mathrm{C} 11)$ indicator can be calculated by the following equation $(E q .1)$ :

$$
F D=\left\{\sum_{m=1}^{12}\left[\frac{q_{m}-Q_{m}}{Q_{m}}\right]^{2}\right\}^{1 / 2}, Q_{m}=\frac{1}{12} \sum_{m=1}^{12} Q_{m}
$$

where $q_{m}$ is the measured annual monthly runoff and $Q_{m}$ is the annual natural monthly runoff. The annual average natural runoff is then evaluated. And the final score is shown in Table 2.

Table 2. Flow process variation degree indicator score

\begin{tabular}{c|c}
\hline Flow process variation index & Score \\
\hline 0.05 & 100 \\
0.1 & 75 \\
0.3 & 50 \\
1.5 & 25 \\
3.5 & 10 \\
5 & 0 \\
\hline
\end{tabular}

The degree of ecological flow (EF) satisfaction (C12) can be calculated by the following equation (Eq. 2):

$$
E F 1=\min \left[\frac{\mathrm{q}^{\mathrm{d}}}{\mathrm{Q}}\right]_{\mathrm{m}=4}^{\mathrm{m}=9}, \mathrm{EF} 2=\min \left[\frac{\mathrm{q}^{\mathrm{d}}}{\mathrm{Q}}\right]_{\mathrm{m}=10}^{\mathrm{m}=3}
$$

where $\mathrm{q}^{\mathrm{d}}$ is the estimated annual runoff, which is the average annual runoff; EF1 is the lowest percentage of the daily average flow from April to September; and EF2 is the lowest percentage of the daily average flow from October to March. Based on the hydrological method to determine the ecological base flow, the EF1 and EF2 assignment values were calculated according to Table 3, with the minimum value of the assignment taken as the final assignment of the indicator.

Riverbank Stability (C21): The Riverbank Stability Index (BKSr) was assessed based on the current status of riverbank erosion, including erosive erosion that has occurred or is likely to occur. 


$$
-4555 \text { - }
$$

The calculation of BKSr can be expressed as follows (Eq. 3):

$$
\mathrm{BKSr}=\frac{\mathrm{SAr}+\mathrm{SCr}+\mathrm{SHr}+\mathrm{SMr}+\mathrm{STr}}{5}
$$

where BKSr is defined as the bank slope stability index score, SAr is the bank slope dip score, $\mathrm{SCr}$ is the bank slope coverage score, $\mathrm{SHr}$ is the bank slope height score, $\mathrm{SMr}$ is the river bank matrix score, and STr is the slope foot scour strength score. The specific scoring criteria are shown in Table 4.

\begin{tabular}{|c|c|c|c|c|}
\hline \multirow{2}{*}{ Grading } & \multirow{2}{*}{$\begin{array}{l}\text { Qualitative } \\
\text { description }\end{array}$} & \multicolumn{2}{|c|}{ Recommended base flow standard (annual average flow percentage) } & \multirow{2}{*}{ Score } \\
\hline & & $\begin{array}{c}\text { EF1: General water period } \\
\text { (October-March) }\end{array}$ & $\begin{array}{l}\text { EF2: Fish spawning period } \\
\text { (April-September) }\end{array}$ & \\
\hline 1 & maximum & $200 \%$ & $200 \%$ & 100 \\
\hline 2 & optimal & $60-100 \%$ & $60-100 \%$ & 100 \\
\hline 3 & excellent & $40 \%$ & $60 \%$ & 100 \\
\hline 4 & very good & $30 \%$ & $50 \%$ & 100 \\
\hline 5 & good & $20 \%$ & $40 \%$ & 80 \\
\hline 6 & general & $10 \%$ & $30 \%$ & 40 \\
\hline 7 & poor & $10 \%$ & $10 \%$ & 20 \\
\hline 8 & very poor & $<10 \%$ & $<10 \%$ & 0 \\
\hline
\end{tabular}

Table 3. Staging base flow standard and score

\begin{tabular}{|c|c|c|c|c|}
\hline $\begin{array}{c}\text { Bank slope } \\
\text { characteristics }\end{array}$ & Stable & Basically stable & Secondary unstable & Unstable \\
\hline Score & 90 & 75 & 25 & 0 \\
\hline $\begin{array}{l}\text { Slope inclination } \\
\text { (degrees) }(<)\end{array}$ & 15 & 30 & 45 & 60 \\
\hline $\begin{array}{c}\text { Vegetation coverage (\%) } \\
(>)\end{array}$ & $75 \%$ & $50 \%$ & $25 \%$ & $0 \%$ \\
\hline Slope height $(\mathrm{m})(<)$ & 1 & 2 & 3 & 5 \\
\hline Matrix (category) & Bedrock & Rocky bank & Clay river bank & Non-clay river bank \\
\hline Riverbank scouring & No flushing signs & Mild scouring & Moderate scouring & Severe scouring \\
\hline $\begin{array}{c}\text { General } \\
\text { characterization }\end{array}$ & $\begin{array}{l}\text { In the near future, } \\
\text { the river bank will } \\
\text { not be deformed and } \\
\text { destroyed, and no } \\
\text { soil loss will occur. }\end{array}$ & $\begin{array}{l}\text { The riparian structure } \\
\text { has signs of loosening } \\
\text { development and soil } \\
\text { erosion, but it will not } \\
\text { be deformed and } \\
\text { destroyed in the near } \\
\text { future. }\end{array}$ & $\begin{array}{c}\text { The development trend } \\
\text { of loose cracks on the } \\
\text { river bank is obvious. } \\
\text { Under certain } \\
\text { conditions, the river } \\
\text { bank can be deformed } \\
\text { and destroyed, with } \\
\text { moderate soil erosion. }\end{array}$ & $\begin{array}{l}\text { The water and soil } \\
\text { loss on the river bank } \\
\text { is serious, and large } \\
\text { deformation and } \\
\text { damage may occur at } \\
\text { any time, or damage } \\
\text { may have already } \\
\text { occurred. }\end{array}$ \\
\hline
\end{tabular}

Table 4. Evaluation criteria for river bank stability indicators 
Vegetation coverage on river banks (C22): Also known as changes in biomass indicators; vegetation can be separated from water and soil. This process is closely related to plant transpiration, interception of sunlight, photosynthesis, and net primary productivity. This coverage is calculated as follows (Eq. 4):

$$
\text { NDVI }=\frac{\text { Band } 2-\text { Band } 1}{\text { Band } 2+\text { Band } 1}
$$

where Band 2 and Band1 are derived from MOD13Q1 satellite band data. And the final score is shown in Table 5.

Table 5. Riverbank vegetation coverage index score table

\begin{tabular}{c|c}
\hline NDVI & Score \\
\hline 0.4 & 100 \\
0.3 & 74.9 \\
0.2 & 47 \\
0.1 & 24.6 \\
0.05 & 9.7 \\
0 & 0 \\
\hline
\end{tabular}

Degree of human activity in the riparian zone (C23): A riparian human impact assessment was performed in the assessment of the river section using a method for reducing the corresponding score for each human activity. A river section with all 9 types of activities listed below was given 100 points, with corresponding points being deducted according to the type of human activity and its position, with a lowest score of 0 . The specific scoring criteria are shown in Table 6.

Table 6. Standards for human activities in the riparian zone

\begin{tabular}{|c|c|c|c|c|}
\hline \multirow[b]{2}{*}{ NO. } & \multirow[b]{2}{*}{$\begin{array}{l}\text { Type of human } \\
\text { activity }\end{array}$} & \multicolumn{3}{|c|}{ Location } \\
\hline & & $\begin{array}{c}\text { Inside the river } \\
\text { (within the waterline) }\end{array}$ & Riparian zone & $\begin{array}{l}\text { The riparian zone is adjacent to the land } \\
\text { (within } 10 \mathrm{~m} \text { of a small river and within } \\
\mathbf{3 0} \mathrm{m} \text { of a large river) }\end{array}$ \\
\hline 1 & Rigid masonry & & -5 & \\
\hline 2 & Sand mining & -30 & -40 & \\
\hline 3 & $\begin{array}{c}\text { Coastal buildings } \\
\text { (houses) }\end{array}$ & -15 & -10 & -5 \\
\hline 4 & Highway (or railway) & -5 & -10 & -5 \\
\hline 5 & Landfill or dumping & & -60 & -40 \\
\hline 6 & Riverside park & & -5 & -2 \\
\hline 7 & Pipeline & -5 & -5 & -2 \\
\hline 8 & Agricultural cultivation & & -15 & -5 \\
\hline 9 & Livestock farming & & -10 & -5 \\
\hline
\end{tabular}


River connection barrier condition (C24): The final score of C24 is from Table 7.

Table 7. Dam barrier identification table

\begin{tabular}{c|c|c}
\hline Fish migration barrier & $\begin{array}{c}\text { Water quantity and material circulation barrier } \\
\text { characteristics }\end{array}$ & Score \\
\hline Unobstructed & No regulation of runoff & 0 \\
\hline There is a fish channel and it is running & Adjusting the runoff, the discharge flow meets the \\
normally & ecological base flow & -1 \\
\hline $\begin{array}{c}\text { No fishway, blocking the migration of } \\
\text { some fish }\end{array}$ & $\begin{array}{c}\text { The runoff is regulated, and the discharge flow does not } \\
\text { satisfy the ecological base flow }\end{array}$ & -2 \\
\hline The migration channel is completely & Partial time leads to interruption & -20 \\
\hline
\end{tabular}

The calculation of the natural wetland retention rate $(\mathrm{C} 25)$ can be expressed as follows (Eq. 5):

$$
\mathrm{NWL}=\frac{\mathrm{AW}}{\mathrm{AWR}_{\mathrm{n}}}
$$

where NWL is the natural wetland retention rate, AW is the natural wetland area $\left(\mathrm{km}^{2}\right)$ for the assessment base year, and $\mathrm{AWR}_{\mathrm{n}}$ is the historical wetland area $\left(\mathrm{km}^{2}\right)$. The final score of $\mathrm{C} 25$ is from Table 8.

Table 8. Natural wetland retention rate assignment standard table

\begin{tabular}{c|c|c}
\hline Natural wetland retention rate & Score & Description \\
\hline $93 \%$ & 100 & Close to reference conditions \\
\hline $86 \%$ & 75 & Small difference from reference conditions \\
\hline $72 \%$ & 50 & Moderately different from reference conditions \\
\hline $44 \%$ & 25 & A large difference from reference conditions \\
\hline $16 \%$ & 0 & Significantly different from the reference status \\
\hline
\end{tabular}

Dissolved Oxygen Concentration (C31): The monthly average concentration of 12 months was used to classify the data into 2 groups, the flood season and the non-flood period. The scores of the flood season and the non-flood period were then evaluated. The specific scoring criteria are shown in Table 9.

Table 9. DO water quality indicator score criteria

\begin{tabular}{c|c|c|c|c|c|c}
\hline DO $(\mathrm{mg} / \mathrm{L})(>)$ & Saturation rate 90\% (or 7.5) & 6 & 5 & 3 & 2 & 0 \\
\hline DO indicator assignment & 100 & 80 & 60 & 30 & 10 & 0 \\
\hline
\end{tabular}


Oxygen-poor organic pollution status (C32): Permanganate index, 5-day biochemical oxygen demand, and ammonia nitrogen were assigned separately. The monthly average concentration of the 12-month evaluation year was selected and the average value was calculated based on the flood season and the non-flood period. The scores of the flood season and the non-flood period were separately assessed. The average of the scores of the three water quality projects was taken as the oxygen-consuming organic pollution status. The indicator calculation can be expressed as Eq. 6:

$$
\mathrm{OCPr}=\frac{(\mathrm{CODMNr}+\mathrm{BODr}+\mathrm{NH} 3 \mathrm{Nr})}{3}
$$

The specific scoring criteria of C32 are shown in Table 10.

Table 10. Oxygen consumption index

\begin{tabular}{c|c|c|c|c|c}
\hline Permanganate index (mg/L) & 2 & 4 & 6 & 10 & 15 \\
\hline 5-day biochemical oxygen demand (BOD5) (mg/L) & 3 & 3.5 & 4 & 6 & 10 \\
\hline Ammonia nitrogen (NH3-N) (mg/L) & 0.15 & 0.5 & 1 & 1.5 & 2 \\
\hline Score & 100 & 80 & 60 & 30 & 0 \\
\hline
\end{tabular}

Heavy metal pollution status (C33): The average monthly concentrations of mercury, cadmium, chromium, lead, and arsenic concentrations were determined according to 12 months of assessment. The averages were determined based on the flood season and non-flood period. The scores of the flood season and non-flood period were then evaluated. The minimum score was divided into the scores of the water quality project, and the lowest scores of the 5 water quality projects were assigned as the indicators of the heavy metal pollution status. The calculation can be expressed as Eq. 7:

$$
\mathrm{HM} \operatorname{Pr}=\operatorname{Min}(\operatorname{Arr}, \mathrm{Hgr}, \mathrm{Cdr}, \mathrm{Crr}, \mathrm{Pbr})
$$

where HM Pr is the heavy metal pollution index factor and Arr, Hgr, Cdr, Crr, and Pbr are factors assigned to the corresponding metals. The specific scoring criteria are shown in Table 11.

Table 11. Standards for assigning indicators of heavy metal pollution status

\begin{tabular}{c|c|c|c}
\hline Arsenic & 0.05 & 0.025 & 0.1 \\
\hline HG & 0.00005 & 0.0001 & 0.001 \\
\hline Cadmium & 0.001 & 0.005 & 0.01 \\
\hline Chromium (hexavalent) & 0.01 & 0.05 & 0.1 \\
\hline Lead & 0.01 & 0.05 & 0.1 \\
\hline Score & 100 & 60 & 0 \\
\hline
\end{tabular}


Water function area compliance index (C34): The water function area that met the number of assessments during the year at least $80 \%$ of the time was defined as the water quality standard water function area. The calculation method for the water quality compliance index of the water function area was that 20 points were deducted when the river section was not up to standard.

Fish Bio-Loss Index (C41): This index refers to the assessment of the difference between the current number of fish species in a river segment and the number of fish species in the historical reference system. The surveyed fish species did not include alien species. The fish bio-loss index is calculated as follows (Eq. 8),

$$
\mathrm{FOE}=\frac{\mathrm{FO}}{\mathrm{FE}}
$$

where FOE is the fish bio-loss index, FO is the number of fish species obtained from the survey of a particular river segment, and FE is the number of fish species in the section based on historical assessment.

Sewage centralized treatment efficiency index (C51): From a basic survey of the operational status of sewage treatment plants in the Xiangjiang River Basin, the scores of the sewage centralized treatment efficiency indicators could be determined. The specific scoring criteria are shown in Table 12.

Table 12. Sewage centralized treatment efficiency index score

\begin{tabular}{c|c}
\hline Sewage centralized treatment efficiency index & Score \\
\hline 1 & 100 \\
\hline 0.95 & 80 \\
\hline 0.8 & 70 \\
\hline 0.75 & 50 \\
\hline 0 & 0 \\
\hline
\end{tabular}

Soil erosion control index (C52): This index indicates the intensity of soil erosion and the implementation of control measures throughout the river. The calculation of this index can be expressed as follows (Eq. 9):

$$
\mathrm{SECI}=\frac{\mathrm{SEC}}{\mathrm{SE}}
$$

where SECI represents the soil erosion control index, SE represents the area of soil erosion in the region, and SEC represents the planned area of key treatment of soil erosion in the region.

Hazard Source Risk Index (C53): This index refers to assessed sources of heavy metal pollution and sources of toxic and hazardous substances in the riparian zone and its adjacent land areas. For the assessment of river segments, a hazard source risk assessment was carried out using a method in which each hazard source reduces the total number of points by its corresponding score. River segments without danger 
sources were assigned a value of 100 points, and the corresponding points were deducted according to the type of danger source and its position, untila minimum value of 0 points. Each state-level industrial park in a river segment has an association deduction of 5 points was reached. Each provincial industrial park results in a deduction of 3 points.

Flood Control Indicators (C61): River Flood Control Indicators (FLD) are used to assess the safe discharge capacity of a river course. The calculation of this index can be expressed as follows (Eq. 10):

$$
\mathrm{FLD}=\frac{\sum_{\mathrm{N}=1}^{\mathrm{NS}}\left(\mathrm{RIVL}_{\mathrm{n}} \times \mathrm{RIVWF}_{\mathrm{n}} \times \mathrm{RIVB}_{\mathrm{n}}\right)}{\sum_{\mathrm{N}=1}^{\mathrm{NS}}\left(\mathrm{RIVL}_{\mathrm{n}} \times \mathrm{RIVWF}_{\mathrm{n}}\right)}
$$

where FLD is the river flood control index and RIVL $n$ is the length of river segment nthe number of river segments divided by the river according to the flood control plan is evaluated. $\mathrm{RIVB}_{\mathrm{n}}$ is assigned according to whether the flood control project of a given river segment meets the planning requirements, where $\operatorname{RIVB}_{\mathrm{n}}=1$ when the standard is met and $\mathrm{RIVB}_{\mathrm{n}}=0$ when the standard is not met. RIVWF is the recurrence period of the planned flood control standard for a given river segment (e.g., 100 years). The scoring criteria are shown in Table 13.

Table 13. Flood control index assignment standard

\begin{tabular}{c|c|c|c|c|c}
\hline Score & 100 & 75 & 50 & 25 & 0 \\
\hline FLD & $100 \%$ & $75 \%$ & $50 \%$ & $25 \%$ & $0 \%$ \\
\hline
\end{tabular}

Public Satisfaction Indicator (C62): This indicator is calculated based on the public participation survey statistics. The public questionnaire included many parameters: the basic information of the participants, the relationship between the participants, the participants' assessment of the river's water volume, water quality, river beach conditions, fish status and the river suitability, the participants' understanding of the above aspects, and an overall assessment of the river conditions.According to the Technical Guidelines for River and Lake Health Evaluation, scores are assigned according to the total number of responses for options in the table, with the assignment criteria shown in Table 14.

Table 14. River safety assessment public survey indicator assignment criteria

\begin{tabular}{c|c|c}
\hline Option type & Option & Score \\
\hline \multirow{3}{*}{ Option 1 } & $\mathrm{A}$ & 100 \\
\cline { 2 - 3 } & $\mathrm{B}$ & 75 \\
\cline { 2 - 3 } & $\mathrm{C}$ & 50 \\
\hline \multirow{3}{*}{ Option 2 } & $\mathrm{D}$ & 0 \\
\cline { 2 - 3 } & $\mathrm{A}$ & 100 \\
\cline { 2 - 3 } & $\mathrm{B}$ & 50 \\
\hline \multirow{2}{*}{ Option 3 } & $\mathrm{C}$ & 0 \\
\cline { 2 - 3 } & $\mathrm{A}$ & 100 \\
\hline
\end{tabular}


Centralized drinking water source safety assessment index (C63): The drinking water source refers to the water source area that provides residents' living and public service water intake projects. This index was calculated using the centralized drinking water source safety assessment index system from the National Important Drinking Water Source Safety Assessment Guide. This guide includes a water quality assessment of 30 points, a water quality assurance assessment of 40 points, a monitoring assurance assessment score of 15 points, and a management assurance assessment score of 15 points. The maximum evaluation of the centralized drinking water source is 100 points. The average value was taken as the safety assurance assessment index of the centralized drinking water source.

\section{Index weight calculation}

This study selected the current mature and general AHP method to calculate the index weights, which can make this process clear, quantifying qualitative problems and requiring fewer data. There are three basic steps. The first step was the establishment of a hierarchical structure. The second step concerned the construction of a pairwise comparison judgment matrix. The third step involved the hierarchical ranking calculation and consistency test, followed by an $n$ index weight calculation. The AHP method generally uses a scale of 1-9 and its reciprocal when constructing the pairwise comparison judgment matrix (Table 15).

Table 15. Judgment matrix scale and its corresponding meanings

\begin{tabular}{c|c}
\hline Scaling & Implication \\
\hline 1 & Equally important to a function \\
3 & Slightly more important relative to a certain function \\
7 & Significantly important relative to a function \\
9 & Strongly important relative to a function \\
$2,4,6,8$ & Extremely important relative to a function \\
& $\begin{array}{c}\text { Intermediate conditions between two adjacent judgments } \\
\text { (Reciprocal, results of geminate contrast and reversal, } \\
\text { namely index } i \text { is relative to index } j)\end{array}$ \\
\hline
\end{tabular}

\section{Building a judgment matrix}

Experts in three related fields (\#1, \#2, \#3) determined the importance of the indicators. The importance judgment matrices of the factor layer and the indicator layer were obtained. The final weight determination depended on the average values of the three experts (Tables 16,17,18).

There are many methods for normalizing the eigenvectors of the judgment matrix. The maximum eigenvalues and eigenvectors of the judgment matrix were calculated using the square root method. The judgment matrix is $U=\left(u_{i, j}\right)_{n \times n}$, where $u_{i, j}$ indicates that the importance of factor $i$ is higher than that of factor $j$ relative to the previous level. $\mathrm{n}$ is the order of the matrix. 
Table 16. Judgment matrix of the water ecological security indicator system of the Xiangjiang River Basin (\#1)

\begin{tabular}{|c|c|c|c|c|c|c|c|c|c|c|c|c|c|}
\hline A & & \multicolumn{2}{|l|}{$\mathrm{B}_{1}$} & \multicolumn{2}{|l|}{$\mathrm{B}_{2}$} & \multicolumn{2}{|l|}{$\mathrm{B}_{3}$} & \multicolumn{2}{|l|}{$\mathrm{B}_{4}$} & \multicolumn{2}{|l|}{$\mathrm{B}_{5}$} & \multicolumn{2}{|l|}{$\mathrm{B}_{6}$} \\
\hline $\mathrm{B}_{1}$ & & \multicolumn{2}{|l|}{1} & \multicolumn{2}{|l|}{7} & \multicolumn{2}{|l|}{1} & \multicolumn{2}{|l|}{5} & \multicolumn{2}{|l|}{5} & \multicolumn{2}{|l|}{1} \\
\hline $\mathrm{B}_{2}$ & & \multicolumn{2}{|l|}{$1 / 7$} & \multicolumn{2}{|l|}{1} & \multicolumn{2}{|l|}{$1 / 7$} & \multicolumn{2}{|l|}{$1 / 3$} & \multicolumn{2}{|l|}{$1 / 5$} & \multicolumn{2}{|l|}{$1 / 7$} \\
\hline $\mathrm{B}_{3}$ & & \multicolumn{2}{|l|}{1} & \multicolumn{2}{|l|}{7} & \multicolumn{2}{|l|}{1} & \multicolumn{2}{|l|}{7} & \multicolumn{2}{|l|}{5} & \multicolumn{2}{|l|}{1} \\
\hline $\mathrm{B}_{4}$ & & \multicolumn{2}{|l|}{$1 / 5$} & \multicolumn{2}{|l|}{3} & \multicolumn{2}{|l|}{$1 / 7$} & \multicolumn{2}{|l|}{1} & \multicolumn{2}{|l|}{$1 / 3$} & \multicolumn{2}{|l|}{$1 / 2$} \\
\hline $\mathrm{B}_{5}$ & & \multicolumn{2}{|l|}{$1 / 5$} & \multicolumn{2}{|l|}{5} & \multicolumn{2}{|l|}{$1 / 5$} & \multicolumn{2}{|l|}{3} & 1 & & $1 / 5$ & \\
\hline $\mathrm{B}_{6}$ & & 1 & & 7 & & 1 & & 2 & & 5 & & 1 & \\
\hline $\mathrm{B}_{1}$ & $\mathrm{C}_{11}$ & $\mathrm{C}_{12}$ & $\mathrm{~B}_{2}$ & $\mathrm{C}_{21}$ & $\mathrm{C}_{22}$ & $\mathrm{C}_{23}$ & $\mathrm{C}_{24}$ & $\mathrm{C}_{25}$ & $\mathrm{~B}_{3}$ & $\mathrm{C}_{31}$ & $\mathrm{C}_{32}$ & $\mathrm{C}_{33}$ & $\mathrm{C}_{34}$ \\
\hline $\mathrm{C}_{11}$ & 1 & $1 / 5$ & $\mathrm{C}_{21}$ & 1 & 5 & 5 & 3 & 5 & $\mathrm{C}_{31}$ & 1 & 1 & $1 / 3$ & $1 / 7$ \\
\hline $\mathrm{C}_{12}$ & 5 & 1 & $\mathrm{C}_{22}$ & $1 / 5$ & 1 & 1 & $1 / 2$ & 1 & $\mathrm{C}_{32}$ & 1 & 1 & $1 / 3$ & $1 / 7$ \\
\hline & & & $\mathrm{C}_{23}$ & $1 / 5$ & 1 & 1 & $1 / 2$ & $1 / 2$ & $\mathrm{C}_{33}$ & 3 & 3 & 1 & $1 / 7$ \\
\hline & & & $\mathrm{C}_{24}$ & $1 / 3$ & 2 & 2 & 1 & 2 & $\mathrm{C}_{34}$ & 7 & 7 & 7 & 1 \\
\hline & & & $\mathrm{C}_{25}$ & $1 / 5$ & 1 & 2 & $1 / 2$ & 1 & & & & & \\
\hline $\mathrm{B}_{4}$ & $\mathrm{C}_{41}$ & & $\mathrm{~B}_{5}$ & $\mathrm{C}_{51}$ & $\mathrm{C}_{52}$ & $\mathrm{C}_{53}$ & & & $\mathrm{~B}_{6}$ & $\mathrm{C}_{61}$ & $\mathrm{C}_{62}$ & $\mathrm{C}_{63}$ & \\
\hline $\mathrm{C}_{41}$ & 1 & & $\mathrm{C}_{51}$ & 1 & 7 & 5 & & & $\mathrm{C}_{61}$ & 1 & 5 & 2 & \\
\hline & & & $\mathrm{C}_{52}$ & $1 / 7$ & 1 & $1 / 3$ & & & $\mathrm{C}_{62}$ & $1 / 5$ & 1 & $1 / 5$ & \\
\hline & & & $\mathrm{C}_{53}$ & $1 / 5$ & 3 & 1 & & & $\mathrm{C}_{63}$ & $1 / 2$ & 5 & 1 & \\
\hline
\end{tabular}

Table 17. Judgment matrix of the water ecological security indicator system of the Xiangjiang River Basin (\#2)

\begin{tabular}{|c|c|c|c|c|c|c|c|c|c|c|c|c|c|}
\hline A & & \multicolumn{2}{|l|}{$\mathrm{B}_{1}$} & \multicolumn{2}{|l|}{$\mathrm{B}_{2}$} & \multicolumn{2}{|l|}{$\mathrm{B}_{3}$} & \multicolumn{2}{|l|}{$\mathrm{B}_{4}$} & \multicolumn{2}{|l|}{$\mathrm{B}_{5}$} & \multicolumn{2}{|l|}{$\mathrm{B}_{6}$} \\
\hline $\mathrm{B}_{1}$ & & \multicolumn{2}{|l|}{1} & \multicolumn{2}{|l|}{3} & \multicolumn{2}{|l|}{$1 / 3$} & \multicolumn{2}{|l|}{$1 / 3$} & \multicolumn{2}{|l|}{2} & \multicolumn{2}{|l|}{2} \\
\hline $\mathrm{B}_{2}$ & & \multicolumn{2}{|l|}{$1 / 3$} & \multicolumn{2}{|l|}{1} & \multicolumn{2}{|l|}{$1 / 4$} & \multicolumn{2}{|l|}{$1 / 4$} & \multicolumn{2}{|l|}{$1 / 3$} & \multicolumn{2}{|l|}{$1 / 2$} \\
\hline $\mathrm{B}_{3}$ & & \multicolumn{2}{|l|}{3} & \multicolumn{2}{|l|}{4} & \multicolumn{2}{|l|}{1} & \multicolumn{2}{|l|}{2} & \multicolumn{2}{|l|}{2} & \multicolumn{2}{|l|}{2} \\
\hline $\mathrm{B}_{4}$ & & \multicolumn{2}{|l|}{3} & \multicolumn{2}{|l|}{4} & \multicolumn{2}{|l|}{$1 / 2$} & \multicolumn{2}{|l|}{1} & \multicolumn{2}{|l|}{2} & \multicolumn{2}{|l|}{2} \\
\hline $\mathrm{B}_{5}$ & & \multicolumn{2}{|l|}{$1 / 2$} & \multicolumn{2}{|l|}{3} & \multicolumn{2}{|l|}{$1 / 2$} & \multicolumn{2}{|l|}{$1 / 2$} & 1 & & $1 / 2$ & \\
\hline $\mathrm{B}_{6}$ & & $1 / 2$ & & 2 & & $1 / 2$ & & $1 / 2$ & & 2 & & 1 & \\
\hline $\mathrm{B}_{1}$ & $\mathrm{C}_{11}$ & $\mathrm{C}_{12}$ & $\mathrm{~B}_{2}$ & $\mathrm{C}_{21}$ & $\mathrm{C}_{22}$ & $\mathrm{C}_{23}$ & $\mathrm{C}_{24}$ & $\mathrm{C}_{25}$ & $\mathrm{~B}_{3}$ & $\mathrm{C}_{31}$ & $\mathrm{C}_{32}$ & $\mathrm{C}_{33}$ & $\mathrm{C}_{34}$ \\
\hline $\mathrm{C}_{11}$ & 1 & $1 / 2$ & $\mathrm{C}_{21}$ & 1 & 3 & 2 & 2 & 4 & $\mathrm{C}_{31}$ & 1 & $1 / 3$ & $1 / 3$ & $1 / 3$ \\
\hline $\mathrm{C}_{12}$ & 2 & 1 & $\mathrm{C}_{22}$ & $1 / 3$ & 1 & $1 / 2$ & 2 & 2 & $\mathrm{C}_{32}$ & 3 & 1 & $1 / 2$ & $1 / 2$ \\
\hline & & & $\mathrm{C}_{23}$ & $1 / 2$ & 2 & 1 & 2 & 2 & $\mathrm{C}_{33}$ & 3 & 2 & 1 & 2 \\
\hline & & & $\mathrm{C}_{24}$ & $1 / 2$ & $1 / 2$ & $1 / 2$ & 1 & 2 & $\mathrm{C}_{34}$ & 3 & 2 & $1 / 2$ & 1 \\
\hline & & & $\mathrm{C}_{25}$ & $1 / 4$ & $1 / 2$ & $1 / 2$ & $1 / 2$ & 1 & & & & & \\
\hline $\mathrm{B}_{4}$ & $\mathrm{C}_{41}$ & & $\mathrm{~B}_{5}$ & $\mathrm{C}_{51}$ & $\mathrm{C}_{52}$ & $\mathrm{C}_{53}$ & & & $\mathrm{~B}_{6}$ & $\mathrm{C}_{61}$ & $\mathrm{C}_{62}$ & $\mathrm{C}_{63}$ & \\
\hline $\mathrm{C}_{41}$ & 1 & & $\mathrm{C}_{51}$ & 1 & 4 & 3 & & & $\mathrm{C}_{61}$ & 1 & 4 & $1 / 2$ & \\
\hline & & & $\mathrm{C}_{52}$ & $1 / 4$ & 1 & 2 & & & $\mathrm{C}_{62}$ & $1 / 4$ & 1 & $1 / 3$ & \\
\hline & & & $\mathrm{C}_{53}$ & $1 / 3$ & $1 / 2$ & 1 & & & $\mathrm{C}_{63}$ & 2 & 3 & 1 & \\
\hline
\end{tabular}




$$
-4563-
$$

Table 18. Judgment matrix of the water ecological security indicator system of the Xiangjiang River Basin (\#3)

\begin{tabular}{|c|c|c|c|c|c|c|c|c|c|c|c|c|c|}
\hline $\mathbf{A}$ & & \multicolumn{2}{|l|}{$\mathrm{B}_{1}$} & \multicolumn{2}{|l|}{$\mathrm{B}_{2}$} & \multicolumn{2}{|l|}{$\mathrm{B}_{3}$} & \multicolumn{2}{|l|}{$\mathrm{B}_{4}$} & \multicolumn{2}{|l|}{$\mathrm{B}_{5}$} & \multicolumn{2}{|l|}{$\mathrm{B}_{6}$} \\
\hline $\mathrm{B}_{1}$ & & \multicolumn{2}{|l|}{1} & \multicolumn{2}{|l|}{5} & \multicolumn{2}{|l|}{$1 / 3$} & \multicolumn{2}{|l|}{1} & \multicolumn{2}{|l|}{3} & \multicolumn{2}{|l|}{9} \\
\hline $\mathrm{B}_{2}$ & & \multicolumn{2}{|l|}{$1 / 5$} & \multicolumn{2}{|l|}{1} & \multicolumn{2}{|l|}{$1 / 7$} & \multicolumn{2}{|l|}{$1 / 5$} & \multicolumn{2}{|l|}{1} & \multicolumn{2}{|l|}{5} \\
\hline $\mathrm{B}_{3}$ & & \multicolumn{2}{|l|}{3} & \multicolumn{2}{|l|}{7} & \multicolumn{2}{|l|}{1} & \multicolumn{2}{|l|}{2} & \multicolumn{2}{|l|}{3} & \multicolumn{2}{|l|}{9} \\
\hline $\mathrm{B}_{4}$ & & \multicolumn{2}{|l|}{1} & \multicolumn{2}{|l|}{5} & \multicolumn{2}{|l|}{$1 / 2$} & \multicolumn{2}{|l|}{1} & \multicolumn{2}{|l|}{3} & \multicolumn{2}{|l|}{7} \\
\hline $\mathrm{B}_{5}$ & & \multicolumn{2}{|l|}{$1 / 3$} & \multicolumn{2}{|l|}{1} & \multicolumn{2}{|l|}{$1 / 3$} & \multicolumn{2}{|l|}{$1 / 3$} & 1 & & 3 & \\
\hline $\mathrm{B}_{6}$ & & $1 / 9$ & & $1 / 5$ & & $1 / 9$ & & $1 / 7$ & & $1 / 3$ & & 1 & \\
\hline $\mathbf{B}_{1}$ & $\mathrm{C}_{11}$ & $\mathrm{C}_{12}$ & $\mathbf{B}_{2}$ & $\mathrm{C}_{21}$ & $\mathrm{C}_{22}$ & $\mathrm{C}_{23}$ & $\mathrm{C}_{24}$ & $\mathrm{C}_{25}$ & $\mathbf{B}_{3}$ & $\mathrm{C}_{31}$ & $\mathrm{C}_{32}$ & $\mathrm{C}_{33}$ & $\mathrm{C}_{34}$ \\
\hline $\mathrm{C}_{11}$ & 1 & $1 / 3$ & $\mathrm{C}_{21}$ & 1 & $1 / 5$ & $1 / 3$ & $1 / 5$ & 1 & $\mathrm{C}_{31}$ & 1 & 3 & 3 & 3 \\
\hline $\mathrm{C}_{12}$ & 3 & 1 & $\mathrm{C}_{22}$ & 5 & 1 & 1 & $1 / 2$ & 3 & $\mathrm{C}_{32}$ & $1 / 3$ & 1 & 2 & 2 \\
\hline & & & $\mathrm{C}_{23}$ & 3 & 1 & 1 & 1 & 5 & $\mathrm{C}_{33}$ & $1 / 3$ & $1 / 2$ & 1 & 2 \\
\hline & & & $\mathrm{C}_{24}$ & 5 & 2 & 1 & 1 & 3 & $\mathrm{C}_{34}$ & $1 / 3$ & $1 / 2$ & $1 / 2$ & 1 \\
\hline & & & $\mathrm{C}_{25}$ & 1 & $1 / 3$ & $1 / 5$ & $1 / 3$ & 1 & & & & & \\
\hline $\mathbf{B}_{4}$ & $\mathrm{C}_{41}$ & & $\mathbf{B}_{5}$ & $\mathrm{C}_{51}$ & $\mathrm{C}_{52}$ & $\mathrm{C}_{53}$ & & & $\mathbf{B}_{6}$ & $\mathrm{C}_{61}$ & $\mathrm{C}_{62}$ & $\mathrm{C}_{63}$ & \\
\hline $\mathrm{C}_{41}$ & 1 & & $\mathrm{C}_{51}$ & 1 & 7 & 2 & & & $\mathrm{C}_{61}$ & 1 & $1 / 3$ & 1 & \\
\hline & & & $\mathrm{C}_{52}$ & $1 / 7$ & 1 & $1 / 2$ & & & $\mathrm{C}_{62}$ & 3 & 1 & 3 & \\
\hline & & & $\mathrm{C}_{53}$ & $1 / 2$ & 2 & 1 & & & $\mathrm{C}_{63}$ & 1 & $1 / 3$ & 1 & \\
\hline
\end{tabular}

The specific calculation steps can be expressed as follows:

(1) The calculation of the product of each row element of the judgment matrix can be expressed as (Eq. 11):

$$
M_{i}=\prod_{j=1}^{n} u_{i j}
$$

(2) The calculation of the nth root of $M_{i}$ can be expressed as (Eq. 12):

$$
\overline{W_{i}}=\sqrt[n]{M_{i}}
$$

(3) The normalization can be expressed as (Eq. 13)

$$
W_{i}=\frac{\bar{W}_{i}}{\sum_{j=1}^{n} \bar{W}_{j}}
$$


Then, $W=\left(W_{i}, i=1,2, \cdots, n\right)$ indicates the relative priority of each factor, which is the element that constitutes the feature vector $W$ of the judgment matrix, namely, the ranking weight of the corresponding factor of the same level for the relative importance of the previous level factor.

\section{Consistency calculation}

(1) The calculation of the maximum eigenvalue of the judgment matrix can be expressed as (Eq. 14):

$$
\lambda_{\max }=\sum_{i=1}^{n}\left(\frac{\sum_{j=1}^{n} v_{i j} W_{j}}{n W_{i}}\right)
$$

(2) The calculation of the computational judgment matrix consistency index can be expressed as (Eq. 15):

$$
\mathrm{CI}=\frac{\lambda_{\max }-\mathrm{n}}{\mathrm{n}-1}
$$

(3) The calculation of the consistency check coefficient of the judgment matrix can be expressed as (Eq. 16):

$$
C R=\frac{C I}{R I}
$$

When $\mathrm{CR}$ is 0.1 , the maximum eigenvalue can be calculated as:

$\lambda_{\max }^{\prime}=C I(n-1)+n=0.1 R I(n-1)+n$. RI is the average random consistency indicator, which is related to the order $\mathrm{n}$ of the judgment matrix. When $i=1,2, \cdots, n$, the corresponding RI value is shown in Table 19.

Table 19. Average stochastic consistency indicators

\begin{tabular}{cccccccccc}
\hline$n$ & 1 & 2 & 3 & 4 & 5 & 6 & 7 & 8 & 9 \\
\hline$R I$ & 0.00 & 0.00 & 0.58 & 0.90 & 1.12 & 1.24 & 1.32 & 1.41 & 1.45 \\
$\lambda_{\max }^{\prime}$ & - & - & 3.116 & 4.27 & 5.45 & 6.62 & 7.79 & 8.99 & 10.16 \\
\hline
\end{tabular}

In the Table 19, $\mathrm{n}=1$ or 2 and $\mathrm{RI}=0$, because the 1 st- and 2nd-order judgment matrices are always consistent.

When $\mathrm{n} \geq 3, \mathrm{CR}<0.1$, and $\lambda_{\max }<\lambda_{\max }^{\prime}$, the consistency of the comparison judgment matrix is considered to be acceptable; otherwise, the judgment matrix should be properly corrected until $\lambda_{\max }$ is smaller than $\lambda_{\max }^{\prime}$ in order to pass the consistency test and ensure the obtained $\mathrm{W}$ is valid. 


\section{Hierarchical sorting calculation}

Calculating the relative importance scale (also known as the weight vector) of all elements in the same hierarchy to the highest level (total target) is called the total ranking of the hierarchy. The steps for total hierarchical ordering are shown below.

A. The first step is to calculate the weight vector of the importance of all factors at the same level relative to the highest level. This process is carried out from top to bottom and layer by layer.

B. The second step is to calculate the weight vector of nk-1 elements relative to the total target for the k-1th layer:

$$
\mathrm{W}^{(\mathrm{k}-1)}=\left(\mathrm{W}_{1}^{(\mathrm{k}-1)}, \mathrm{W}_{2}^{(\mathrm{k}-1)}, \ldots, \mathrm{Wn}_{(\mathrm{k}-1)}^{(\mathrm{k}-1)}\right)^{\mathrm{T}}
$$

C. The $\mathrm{k}^{\text {th }}$ layer has $\mathrm{nk}$ elements. The single criterion weight vector for an element $\mathrm{j}$ of the previous level $(\mathrm{k}-1)$ is

$$
\mathrm{P}_{\mathrm{j}}^{(\mathrm{k})}=\left(\mathrm{W}_{1 \mathrm{j}}{ }^{(\mathrm{k})}, \mathrm{W}_{2 \mathrm{j}}{ }^{(\mathrm{k})}, \ldots, \mathrm{W}_{\mathrm{nj}}{ }^{(\mathrm{k})}\right) \mathrm{T}
$$

(for the unqualified relationship with the jth element of the k-1 layer, the corresponding Wij takes a value of 0 );

D. The weight vector of the $\mathrm{k}^{\text {th }}$ layer relative to the total target is

$$
\mathrm{W}^{\mathrm{k}}=\left(\mathrm{P}_{1}{ }^{(\mathrm{k})}, \mathrm{P}_{2}{ }^{(\mathrm{k})}, \ldots, \mathrm{P}_{\mathrm{k}-1}{ }^{(\mathrm{k})}\right) \mathrm{W}^{(\mathrm{k}-1)}
$$

\section{Determination of safety assessment criteria}

Based on domestic and foreign research results (Jain et al., 2016; Sun et al., 2016; Zhang et al., 2017; Lyu et al., 2018)[22-25], as well as consultation with experts, the safety assessment grades were determined. The safety assessment scores can be obtained after the standardization of each level of indicators. They are then divided into 5 grades (Table 20).

Table 20. Classification of comprehensive assessment of water ecological security in river basins

\begin{tabular}{cccccc}
\hline Security Level & Very unsafe & Unsafe & General & Safe & Very safe \\
\hline Indicator score interval & {$[0,10)$} & {$[10,30)$} & {$[30,70)$} & {$[70,90)$} & {$[90,100]$} \\
Mean score & 5 & 20 & 50 & 80 & 95 \\
\hline
\end{tabular}

\section{Results}

\section{Indicator comprehensive value}

Through the calculation of indicators and according to the criteria for the corresponding indicators, the evaluation results for each indicator were determined, as shown in Table 21. 
Table 21. Evaluation results of water ecological security indicators for the Xiangjiang River Basin

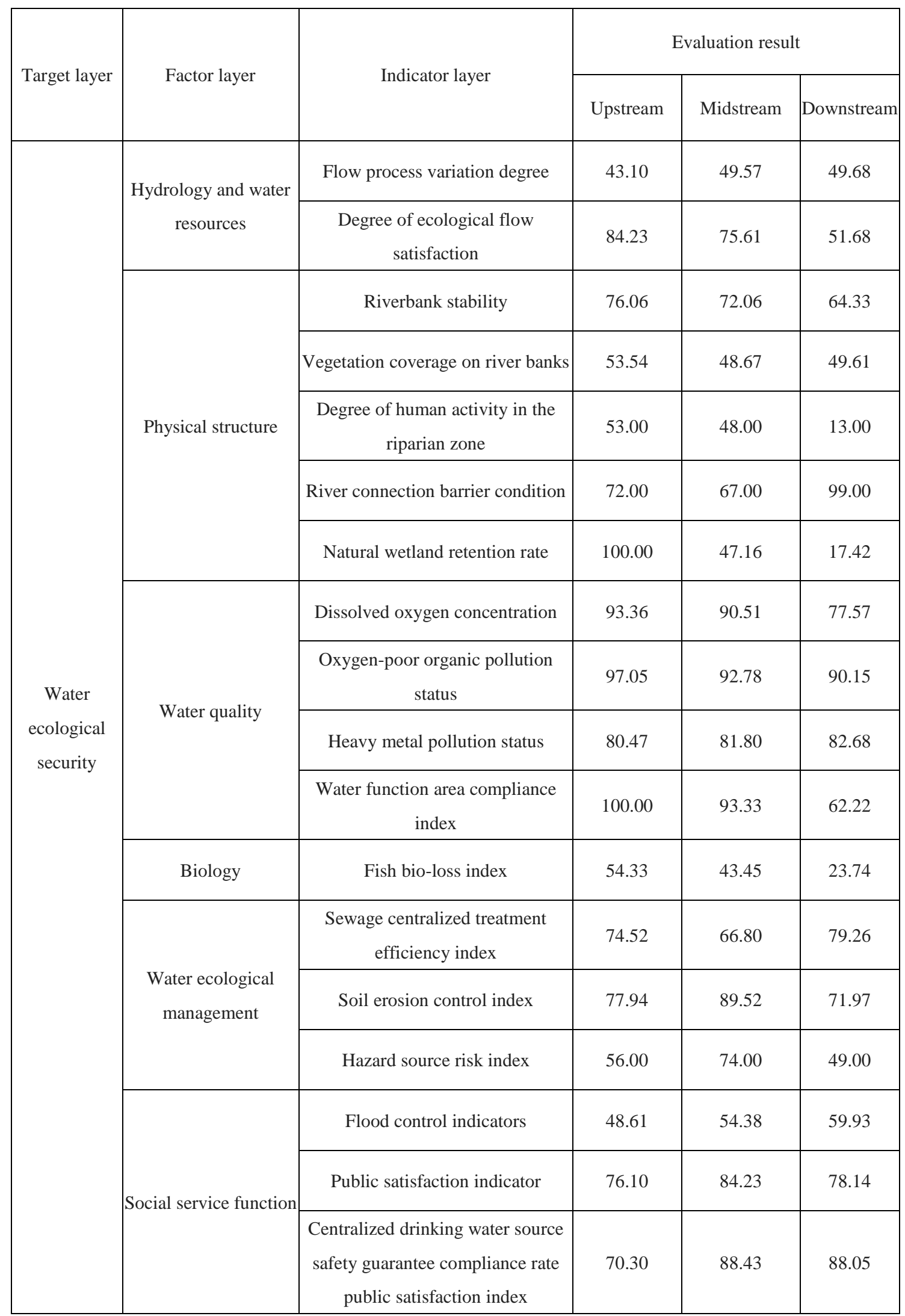




\section{Indicator weights}

The average of the weights of the three experts was comprehensively calculated. The results are shown in Table 22.

Table 22. Weights of water ecological security indicators for the Xiangjiang River Basin

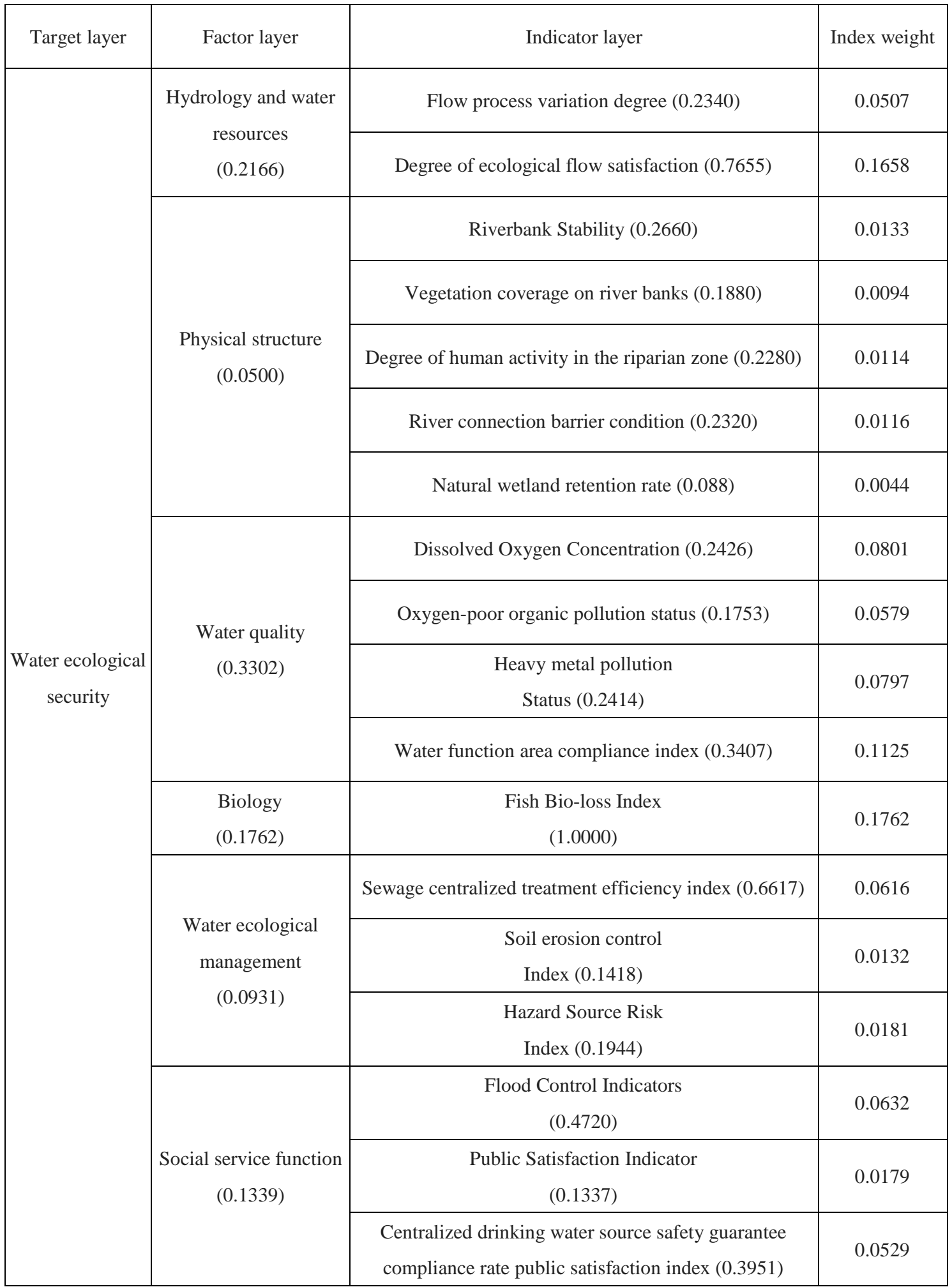




\section{Comprehensive assessment results of water ecological security in the Xiangjiang River Basin}

The comprehensive assessment values of the hydrological and water resources, physical structure, water quality, biological, aquatic ecological management, and social service functions of the upstream, midstream, and downstream portions of the Xiangjiang River Basin were calculated separately. On this basis, overall assessments for the upstream, midstream, and downstream portions of the Xiangjiang River Basin were obtained. The comprehensive evaluation index values of ecological security status are shown in Table 23 for upstream assessment results, Table 24 for midstream assessment results, and Table 25 for downstream assessment results.

Table 23. Results of comprehensive assessments of water ecological security in the upstream portion of the Xiangjiang River Basin

\begin{tabular}{c|c|c}
\hline Objective & \multicolumn{2}{|c}{ Health status of the upstream portion of the Xiangjiang River Basin } \\
\hline Function & Composite indicator score & Evaluation result \\
\hline $\begin{array}{c}\text { Hydrology and water } \\
\text { resources }\end{array}$ & 74.6 & Safe \\
\hline Physical structure & 67.9 & Average \\
\hline Water quality & 93.2 & Very safe \\
\hline Biology & 54.3 & Average \\
\hline $\begin{array}{c}\text { Water ecological } \\
\text { management }\end{array}$ & 71.2 & Safe \\
\hline Social service function & 60.9 & Average \\
\hline $\begin{array}{c}\text { Upstream comprehensive } \\
\text { health level }\end{array}$ & 74.7 & Safe \\
\hline
\end{tabular}

Table 24. Results of comprehensive assessments of water ecological security in the midstream portion of the Xiangjiang River Basin

\begin{tabular}{c|c|c}
\hline Objective & \multicolumn{2}{|c}{ Health status of the midstream portion of the Xiangjiang River Basin } \\
\hline $\begin{array}{c}\text { Function } \\
\text { Hydrology and water } \\
\text { resources }\end{array}$ & 69.5 & Evaluation result \\
\hline Physical structure & 59 & Average \\
\hline Water quality & 89.8 & Average \\
\hline Biology & 43.5 & Safe \\
\hline $\begin{array}{c}\text { Water ecological } \\
\text { management }\end{array}$ & 71.3 & Average \\
\hline Social service function & 71.9 & Safe \\
\hline $\begin{array}{c}\text { Midstream comprehensive } \\
\text { health level }\end{array}$ & 71.6 & Safe \\
\hline
\end{tabular}




$$
-4569-
$$

Table 25. Results of comprehensive assessments of water ecological security in the downstream portion of the Xiangjiang River Basin

\begin{tabular}{c|c|c}
\hline Objective & \multicolumn{2}{|c}{ Health status of the downstream of the Xiangjiang River Basin } \\
\hline Function & Composite indicator score & Evaluation result \\
\hline $\begin{array}{c}\text { Hydrology and water } \\
\text { resources }\end{array}$ & 51.2 & Average \\
\hline Physical structure & 53.9 & Average \\
\hline Water quality & 75.8 & Safe \\
\hline Biology & 23.7 & Unsafe \\
\hline $\begin{array}{c}\text { Water ecological } \\
\text { management }\end{array}$ & 71.2 & Safe \\
\hline $\begin{array}{c}\text { Social service function } \\
\text { Downstream }\end{array}$ & 73.5 & Safe \\
\hline
\end{tabular}

\section{Discussion}

Through the study of water ecological security assessment at home and abroad, it can be seen that the index system is the key point of water ecological security assessment in river basins, and it is worth further study.

\section{Weight comparison of evaluation indicators}

The calculation results of the weights of each indicator from the comprehensive assessment index system for water ecological security are shown in Figure 3.

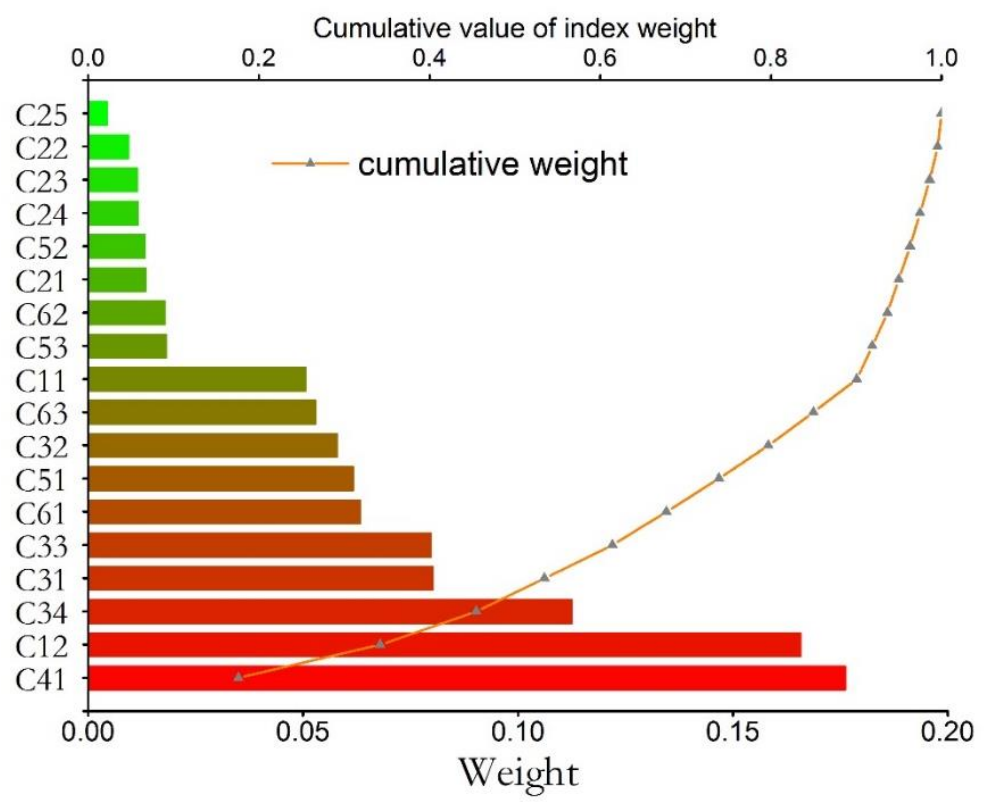

Figure 3. Comparison of various indicator weights of water ecological security 
The figure reflects the importance of indicators in terms of water ecological security assessment. The three most significant indicators are the fish biological loss index, the ecological flow satisfaction level, and water function area compliance, which are important indicators of biological, hydrological, and water resources in the factor layer. The three least important indicators are natural wetland retention, riparian vegetation coverage, and riparian human activity. These indicators reflect the physical structure of the factor layer. Because the indicators with larger weights have a greater impact on the water ecological security of the Xiangjiang River Basin, it is necessary to pay more attention to these indicators.

\section{A comparative analysis of the current status of evaluation indicators}

Figure 4 shows the status of the indicators of the upstream, midstream, and downstream portions of the Xiangjiang River Basin after investigation, reflecting the current safety status of each indicator. The comparison shows that the safety status of the upstream water ecosystem is significantly better than those of the middle and downstream ecosystems, and the comprehensive assessment result of the water ecological security in the midstream is better than that in the downstream section. In terms of specific indicators, i.e., the upstream ecological flow satisfaction level, river bank stability, riparian vegetation coverage, riparian human activity, natural wetland retention, dissolved oxygen concentration, oxygen-consuming organic pollution, water functional zone compliance indicators, and fish life, the scores of the biological loss indicators are higher than those of the middle and downstream sections. In the midstream portion, the soil erosion control index, hazard source risk index, public satisfaction index, and centralized drinking water source safety guarantee compliance rate are better than in other river sections. The downstream river section is superior to the other two river sections in the social service function criterion layer. However, other criterion layers of the downstream section perform poorly. Overall, the natural ecosystem of the upstream portion of the Xiangjiang River Basin is larger, making the water ecology healthier, but there are still some problems in ecological water management. As an important area where soil erosion control has been conducted, the midstream section of the river has done well in terms of ecological water health management, but there are also problems concerning the low retention rate of natural wetlands and the low vegetation coverage on river banks. The ecological quality of the aqueous environment in the downstream reaches of the river is poor. However, this section performs well in terms of water ecological management.
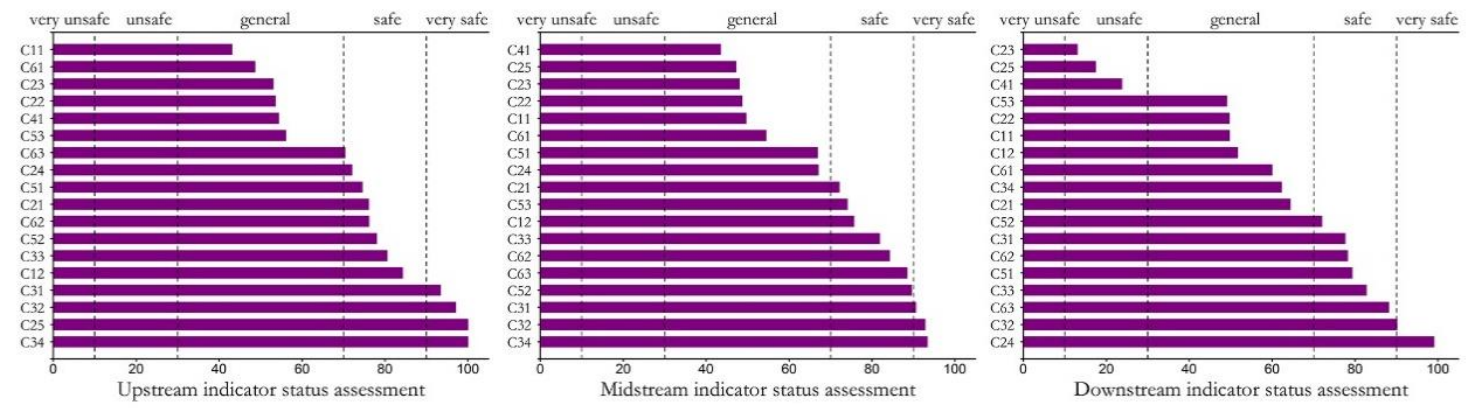

Figure 4. Assessment of the current status of the upstream, midstream, and downstream sections of the Xiangjiang River Basin 


\section{Variation characteristics of indicators}

A comprehensive analysis of the variation of the indicators of the upstream, midstream, and downstream sections of the ecological water security of the Xiangjiang River Basin is shown in Figure 5. In terms of health status, there are 8 indicators of the upstream and midstream sections that are better than the those of the downstream section. These indicators include the water function area compliance indicators, natural wetland retention rate, oxygen-consuming organic pollution status, dissolved oxygen concentration, ecological flow satisfaction degree, river bank stability, fish bio-loss index, and degree of human activity in the riparian zone.

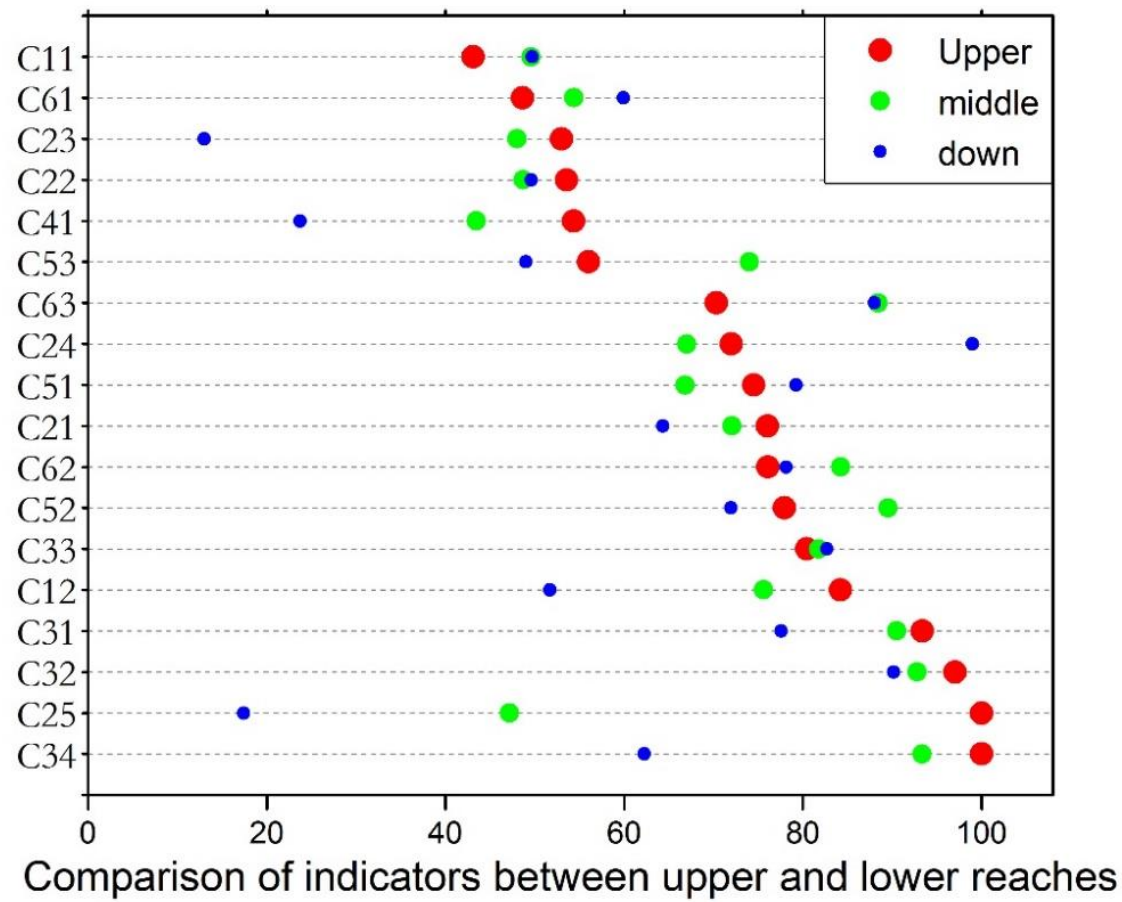

Figure 5. Variations of current indicators of the upstream, midstream, and downstream sections of the Xiangjiang River Basin

These indicators are mainly related to hydrology and water resources, physical structure, water quality and biological elements. It is indicated that from the upstream to the downstream sections of the Xiangjiang River Basin that the health status of the indicators transitions from good to bad, and this situation needs to be paid enough attention. It is worth noting that the natural wetland retention rate along the entire river basin ranges from upstream to downstream is good, general and very poor, indicating that the health level of the index has changed dramatically. In addition, with respect to the entire basin of Xiangjiang River, five indicators (the degree of variation in the flow process, the flood control index, human activity intensity in the riparian zone, riparian vegetation coverage, and the fish bio-loss index) are always at unhealthy levels. This fact merits the attention of concerned researchers and citizens. 


\section{Contribution value of indicators}

Using the weighted values of each indicator of the Xiangjiang River Basin along with the health status of the selected indicators, the contributions of the upstream, midstream, and downstream components of the Xiangjiang River Basin to the total water ecological security can be obtained, as shown in Figure 6. Among them, the top 3 contributing values of the upper reaches are the water function zone compliance index, the ecological flow satisfaction degree, and the fish bio-loss index. The midstream contribution value is consistent with that of the upstream The top 3 contributing values in the lower reaches are water function area compliance, ecological flow satisfaction level and heavy metal pollution status.
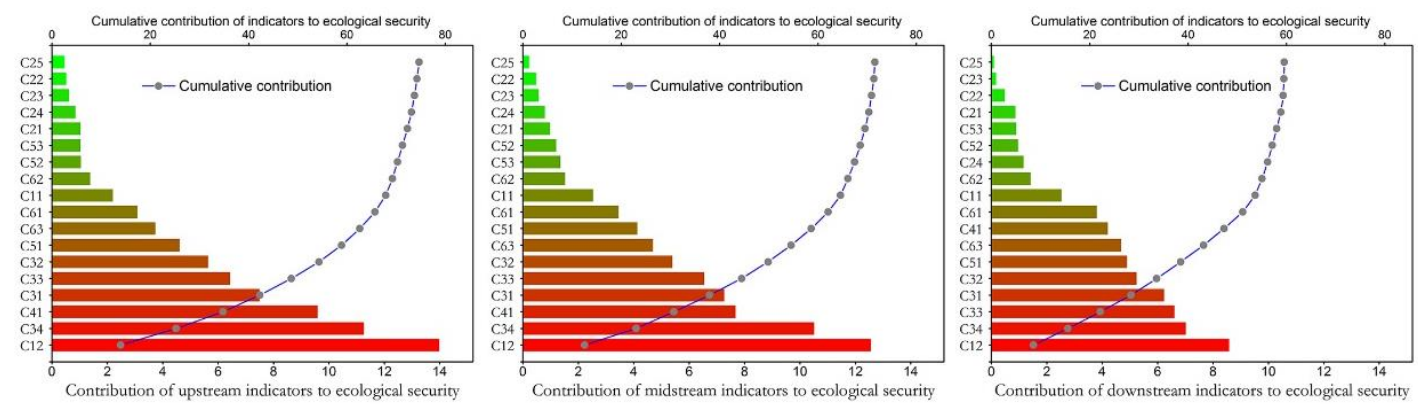

Figure 6. Contribution of the indicators of the upstream, midstream and downstream sections of the Xiangjiang River Basin to water ecological security

\section{Conclusions}

This study considered the effects of physical, chemical, and biological indicators on the stability and sustainability of watersheds from the perspective of water ecological security. The AHP method was used to calculate the comprehensive evaluation index system of the water ecology of the Xiangjiang River Basin. The top 3 indicators reflecting the health of the river are the fish bio-loss index, the degree of ecological flow satisfaction, and the water function area compliance. These are important indicators of biological, hydrological and water resources, as well as water quality in the factor layer. The last three indicators of importance are the natural wetland retention rate, riparian vegetation coverage, and riparian human activity. These indicators represent the physical structure in the factor layer. A comprehensive assessment of the water ecological security of the Xiangjiang River Basin showed that the water quality in the upstream portions of the Xiangjiang River Basin is satisfactory, and the hydrological water resources and water ecological management have been improved, while the physical structure and biological and social service functions are at an average level. The overall ecological security status of the upstream portion of the river is good. The water quality, water ecological management, and social service functions of the midstream are satisfactory. The hydrology and water resources, physical structure and biology are at an average level, and the overall situation of the midstream is safer than the downstream. The water quality, water ecological management and social service functions of the downstream section of the Xiangjiang River Basin are good. The hydrology and water resources and physical structure are at a general level, while the biological health status is unsafe. The overall ecological safety and health status of the 
downstream is at an average level. Based on the health status of the upstream, midstream, and downstream portions of the Xiangjiang River Basin, it can be said that the upstream ecological security level is better than the middle reaches, and that the middle reaches better than the downstream portions.

Acknowledgements. This study was supported by the following Hunan Water Conservancy Science and Technology Project: Research on the water ecological security index system of the Xiangjiang River Basin, contract number: Xiangshui Science and Technology [2015] 186-21; Research on the performance evaluation and benign operation mechanism of urban water ecological civilization construction, contract number: Xiangshui Science and Technology [2016] 194-37.

\section{REFERENCES}

[1] Chen, X., Zhou, C. (2005): Ecological Security: A Review of Domestic and Foreign Research. - Advances in Geography 24(6): 8-20.

[2] Chen, H., Huang, J., Zhang, X., Fu, S. (2013): Dynamic evaluation of water ecological security based on DPSIR conceptual framework. - People's Yellow River 35(9): 34-37.

[3] Chen, Y., Zhi, L., Li, W. (2016): Water and ecological security: dealing with hydroclimatic challenges at the heart of China's Silk Road. - Environmental Earth Sciences 75(10): 881.

[4] Dai, W., Zhang, W., Cheng, Z. (2015): Research on Lanzhou City Water Ecological Security Index System Based on Fuzzy Comprehensive Evaluation. - Arid Zone Research 32(4): 804-809.

[5] Doran, P. (1996): The un commission on sustainable development, 1995. - Environmental Politics 5(1): 100-107.

[6] Haji, G. M., Melesse, A. M., Reddi, L. (2016): Water quality assessment and apportionment of pollution sources using APCS-MLR and PMF receptor modeling techniques in three major rivers of South Florida. - Science of the Total Environment 566-567: 1552-1567.

[7] He, W. (2017): Application of Landscape Ecology to Evaluate Ecological Environment in Small Watersheds. - Environment and Development 29(8): 54-54.

[8] Jain, G. V., Agrawal, R., Bhanderi, R. J. (2016): Estimation of sub-catchment area parameters for Storm Water Management Model (SWMM) using geo-informatics. Geocarto International 31(4): 462-476.

[9] Ji, X., Long, X. L. (2016): A review of the ecological and socioeconomic effects of biofuel and energy policy recommendations. - Renewable \& Sustainable Energy Reviews 61: 41-52.

[10] Li, Y., Xu, Z., Li, Y. (2012): Temporal and Spatial Dynamic Analysis of Landscape Patterns in the Liaohe River Basin Based on Primary Water Ecology. - Earth and Environment 40(3): 000375-384.

[11] Lin, J., Gao, X., Jia, X. (2016): Water ecological security assessment of Taizi River Basin based on PSFR assessment framework. - Environmental Science Research 29(10): 1440-1450. 
[12] Liu, M., Tang, Z., Shi, C. (1989): The reduction of cultivated land is a serious problem that cannot be ignored. - Economic Geography (3): 36-41.

[13] Lyu, H.-M., Shen, J. S., Arulrajah, A. (2018): Assessment of Geohazards and Preventative Countermeasures Using AHP Incorporated with GIS in Lanzhou, China. - Sustainability 10: 304 .

[14] Nödler, K., Tsakiri, M., Aloupi, M. (2016): Evaluation of polar organic micropollutants as indicators for wastewater-related coastal water quality impairment. - Environmental Pollution 211(6): 282-290.

[15] Pan, B., Wang, H., Li, Z. (2017): Macroinvertebrate assemblages in relation to environments in the dongting lake, with implications for ecological management of river-connected lakes affected by dam construction. - Environmental Progress \& Sustainable Energy 36(3).

[16] Rapport, D. J., Thorpe, C., Regier, H. A. (1979): Ecosystem medicine. - Bulletin of the Ecological Society of America 60(4): 180-182.

[17] Schnier, S., Cai, X., Cao, Y. (2016): Importance of Natural and Anthropogenic Environmental Factors to Fish Communities of the Fox River in Illinois. - Environmental Management 57(2): 389-411.

[18] Sun, H., Wang, S., Hao, X. (2016): An Improved Analytic Hierarchy Process Method for the evaluation of agricultural water management in irrigation districts of north China. Agricultural Water Management 179.

[19] Sun, T., Lin, W., Chen, G. (2016): Wetland ecosystem health assessment through integrating remote sensing and inventory data with an assessment model for the Hangzhou Bay, China. - Science of the Total Environment 566-567: 627-640.

[20] Wang, J., Hu, P. (2013): Research on Evaluation System of Water Ecological Civilization. - China Water Resources 15: 39-42.

[21] Wang, Y., Chen, X., Zhu, W. (2016): Research on PSR-based urban water ecological security evaluation system-Taking Linhai City under the "five-water joint treatment" water control mode as an example. - Water Resources Protection 32(2): 82-86.

[22] Yoshimatsu, H., Abe, S. (2006): A review of landslide hazards in Japan and assessment of their susceptibility using an analytical hierarchic process (AHP) method. - Landslides 3: $149-158$

[23] Zhang, X., Liu, C., Men, B., Li, Z., Wang, H. (2013): Construction and Evaluation of Water Ecological Security Index System in the South Wei Canal Basin. - Journal of Beijing Normal University (Natural Science) (6): 626-630.

[24] Zhang, S., Fan, W., Yi, Y. (2017): Evaluation method for regional water cycle health based on nature-society water cycle theory. - Journal of Hydrology 551: 352-364.

[25] Zhang, L., Shi, Y., Zhang, J. (2017): Health Assessment of Daning River Water Ecosystem. - Environmental Science Research 30(7): 1041-1049. 